American Journal of Applied Sciences 9 (2): 196-201, 2012

ISSN 1546-9239

(C) 2012 Science Publications

\title{
Compositional Analysis on Ancient Bricks from Candi Sungai Mas (Site 32/34), Bujang Valley, Kedah
}

\author{
${ }^{1}$ Zuliskandar Ramli, ${ }^{2}$ Nik Hassan Shuhaimi Nik Abd. Rahman, \\ ${ }^{2}$ Adnan Jusoh and ${ }^{3}$ Mohd. Zobir Hussein \\ ${ }^{1}$ Institute of the Malay World and Civilization, \\ The National University of Malaysia, 43600, Bangi, Selangor, Malaysia \\ ${ }^{2}$ Department of History, Faculty of Human Sciences, \\ Sultan Idris Education University, 35900 Tanjong Malim, Perak \\ ${ }^{3}$ Department of Chemistry, Faculty of Science, University Putra Malaysia, Malaysia
}

\begin{abstract}
Problem statement: The significance of Kampung Sungai Mas as an importance archaeology site in Lembah Bujang was revealed in the year 1979 when a cannel was built along Kampung Sungai Mas area. During the construction study of this cannel, thousands of ceramic pieces from India, Middle East, China, Southeast Asia and Europe was discovered, pieces of glasses from Middle East and Europe, stone and glasses beads from Middle East, India and local also pieces and blocks of construction substance from brick and mud stone or slate stone. An inscription also was discovered by one of the villagers when the cannel construction was in progress and this inscription sized estimated $46 \times 23 \mathrm{~cm}$ produced from mud stone and relative estimation based on Pallawa script on the stone and can be dated around 56th century AD. Scientific study done onto Candi Sungai Mas (Site32/34) ancient brick was prominent for archaeology data because since the very beginning, archeologist who was doing research in Kampung Sungai Mas questioned whether the brick discovered was produced by the local society or brought from other area. Approach: Technique used was X-Ray Fluorescence Spectroscopy (XRF) and X-Ray Diffraction (XRD) technique. X-ray Fluorescence Spectroscopy (XRF) can determine the major and trace elements of the bricks whilst XRay Diffraction (XRD) can determine the mineral content of the bricks. Results: Compositional analysis on Candi Sungai Mas (Site 32/34) showed that open firing technique was used to burnt the bricks and that there were two different raw sources used to produce the brick at Kampung Sungai Mas. The raw material used for making the bricks were taken from Bujang River and Muda River basin. Conclusion: It can be concluded here that the protohistory society at Kampung Sungai Mas especially Malay society has succeeded to conquer knowledge and technology on making the brick and showed that we have developed long ago.
\end{abstract}

Key words: Sungai mas, X-Ray Fluorescence Spectroscopy (XRF), X-Ray Diffraction (XRD), bricks

\section{INTRODUCTION}

The discovery of Sungai Mas Incription in Kampung Sungai Mas (Rahman and Yatim, 1990) and revealed thousands of artifacts from the cannel construction project has attracted many scholars and historians. The first excavation attempt in Kampung Sungai Mas was started by Nik Hassan Shuhaimi Nik Abdul Rahman in the year 1981 at land lot 567 (Site 33). The second excavation was carried out by Leong Sau Heng in the same year and the third by Kamaruddin Zakaria in the year 1984. In the year 1985, 2nd IntraASEAN project was carried out and this project was lead by Nik Hassan Shuhaimi Nik Abdul Rahman. The next excavation was carried out by Kamaruddin Zakaria in the year 1990-2002. The recent research carried out at Kampung Sungai Mas started in December 2006 to July 2007 lead by Nik Hassan Shuhaimi from Universiti Kebangsaan Malaysia.

Kampung Sungai Mas (Site 32/34) is a protohistory site that keeps the country various priceless treasures. Sungai Mas was founded earlier from the more north areas that is Pengkalan Bujang. The claim was forwarded by Nik Hassan Shuhaimi Nik Abdul Rahman who has divided it into two phase those are Buddha phase which started from the 5th century till 9th AD

Corresponding Author: Zuliskandar Ramli, Institute of the Malay World and Civilisation, The National University of Malaysia, 43600, Bangi, Selangor, Malaysia 
which focused around Sungai Mas and also southern of Sungai Muda. The second phase from the 9th century to the 14th AD which focused to Pengkalan Bujang which later expanded into trading centre (Shuhaimi, 1984). By the 10th century, the Siwa teaching cult has expanded again around Pengkalan Bujang especially at the middle part and upper part of Sungai Bujang and along Merbok Kechil River (Shuhaimi, 1984).

Sungai Mas area was overlooked by the previous west researchers who had studied a lot the areas at Sungai Bujang, Sungai Batu, Sungai Merbok Kechil, Bukit Batu Pahat, Bukit Meriam, Bukit Penjara, Tikam Batu and area at the south those are Kota Aur and Seberang Prai. The findings of Buddha inscriptions and Buddha head which was chiseled onto greenstone which shows that Sungai Mas (Site 32) has developed since 5th or 6th century (Rahman and Zakaria, 1993) till 13th or 14th century and continues till the era of Kedah Malay Sultanate where this area is still active as trading harbor.

Scientific study onto ancient artifacts found in Bujang Valley have been carried out before this (Ramli et al., 2009; 2011a). Many scientific studies were carried out onto clay pot artifacts where morphology and composition study was carried out to trace source used that is the local clay or not (Chia, 1998; Ramli et al., 2007; 2011b). The clay morphology and composition study at Lembah Bujang also has been carried out and used as referential data for artifact and clay composition comparison in Lembah Bujang. Scientific study is hoped to prove our hypothesis that the brick used as the construction materials at Sungai Mas was produced locally. This can be done by data manipulation with the clay analysis data around the study area.

\section{MATERIALS AND METHODS}

Fractions of twenty six brick samples, taken from different excavation plot was recorded. Samples are taken to lab and treatment onto the samples was carried out. For the characterization of the shards and clay samples, analytical instruments used included X-Ray Diffraction SIEMENS D5000 Diffractometer and XRF Spectrometer Philips Model PW1480. The important of $\mathrm{XRD}$ and XRF techniques are shown in various field of research (Ridha et al., 2009; Woon et al., 2009; Abdullah et al., 2011; Hamzah et al., 2011). Samples for XRF analysis then be grinded into very fine powder form. A mixture of $0.4 \mathrm{~g}$ of sample in powder form (heated at $105^{\circ} \mathrm{C}$ ) and $4.0 \mathrm{~g}$ of flux powder (Johnson Matthey Spectroflux 110) homogeneously been mixed together. The mixture was fused in an electric furnace at $1100^{\circ} \mathrm{C}$, being set for one hour to make a glass.
Homogeneous molten sample than was casted into container and let to be cooled in stagesto become fuse glass with diameter of 32 and $2 \mathrm{~mm}$ thickness. Fused glass samples are prepared for major elements analysis such asSi, Na, K, Ca, Fe, Al, Ti, Mn, $\mathrm{Mg}$ and $\mathrm{P}_{2} \mathrm{O}_{3}$. Press pallet samples then be prepared for trace elements analysis such as $\mathrm{As}, \mathrm{Ba}, \mathrm{La}, \mathrm{Co}, \mathrm{Cr}, \mathrm{Cu}, \mathrm{Ga}, \mathrm{La}, \mathrm{Nb}, \mathrm{Ni}$, $\mathrm{Pb}, \mathrm{Rb}, \mathrm{Hf}, \mathrm{V}, \mathrm{Zn}$ and $\mathrm{Zr}$. Press pallet samples was prepared by mixing $1.0 \mathrm{~g}$ of sample and $6.0 \mathrm{~g}$ of powder boric acid in a sample container and the be pressed to 20psi pressure by hydrolyte pressure instrument. Previous study on the fuss glass and press pallets samples then involved XRF Spectrometer Philips Model PW1480.

\section{RESULTS AND DISCUSSION}

Mineral content analysis was carried out onto 26 brick samples and the analysis results show there is minerals such as quartz, muscovite, microcline, kaolinite, illite, montmorillonite and minor mineral such as chloritiod and tremolite (Table 1). Quartz mineral is seldom found separated from other mineral. Quartz mineral is found in all research samples and the test result also shows that d14-1 sample and s12-2 sample only observed the reading of quartz mineral. This does not mean these samples do not contain other minerals but mineral from mica and feldspar groups has unwind due to high burning. Both samples have been burnt at a higher temperature from other brick samples. The estimated temperature achieved for both samples is as high as $800^{\circ} \mathrm{C}$. The brick samples which contain quartz mineral and muscovite are such as d14-1, i7-2, i7-2, s6-1, s6-2, s6-3, s20-1, s20-2, t18-2, u12-1, u14-1 and $u 15-1$. Brick samples containing mineral such as quartz, muscovite and orthoclase are samples d14-2, i10, s12-1, t18-3 and u15-2. Muscovite mineral is mineral from mica group whereas orthoclase mineral is mineral from feldspar group. Other brick samples containing additional mineral such as sample s12-3 contain quartz mineral, muscovite and chloritiod, sample t16-1 contain minerals such as quartz, muscovite, orthoclase and kaolinite, sample t16-2 contains minerals such as quartz, muscovite and illinite, sample t18-1 contains minerals such as quartz, illite and orthoclase and sample u12-2 contains mineral such as quartz, muscovite, tremolite and montmorillonite.

What is interesting to discuss about these brick samples is due to the existence of minerals such as kaolinite, illite and montmorillonite. The presence of these mineral showed that these samples are burnt below $550^{\circ} \mathrm{C}$. The indifferently or uneven brick burning temperature showed that the bricks has been using open burning technique. 
Am. J. Applied Sci., 9 (2): 196-201, 2012

Table 1: Mineral contents of ancient bricks from Candi Sungai Mas (Site 32/34)

\begin{tabular}{|c|c|}
\hline Sample & Mineral contents \\
\hline d14-1 & $\mathrm{SiO}_{2}$ Kuarza low \\
\hline d14-2 & $\mathrm{SiO}_{2}$ Kuarza low $\mathrm{KAl}_{2} \mathrm{Si}_{3} \mathrm{AlO}_{10}(\mathrm{OH})_{2}$ Muscovite $\mathrm{KAlSi}_{3} \mathrm{O}_{8}$ Orthoclase \\
\hline d14-3 & $\mathrm{SiO}_{2}$ Kuarza low $\mathrm{KAl}_{2} \mathrm{Si}_{3} \mathrm{AlO}_{10}(\mathrm{OH})_{2}$ Muscovite \\
\hline i10 & $\mathrm{SiO}_{2}$ Kuarza low $\mathrm{KAl}_{2} \mathrm{Si}_{3} \mathrm{AlO}_{10}(\mathrm{OH})_{2}$ Muscovite $\mathrm{KAlSi}_{3} \mathrm{O}_{8}$ Orthoclase \\
\hline i7-1 & $\mathrm{SiO}_{2}$ Kuarza low $\mathrm{KAl}_{2} \mathrm{Si}_{3} \mathrm{AlO}_{10}(\mathrm{OH})_{2}$ Muscovite \\
\hline i7-2 & $\mathrm{SiO}_{2}$ Kuarza low $\mathrm{KAl}_{2} \mathrm{Si}_{3} \mathrm{AlO}_{10}(\mathrm{OH})_{2}$ Muscovite \\
\hline i7-3 & $\mathrm{SiO}_{2}$ Kuarza low $\mathrm{KAl}_{2} \mathrm{Si}_{3} \mathrm{AlO}_{10}(\mathrm{OH})_{2}$ Muscovite \\
\hline q14-1 & $\mathrm{SiO}_{2}$ Kuarza low $\mathrm{KAl}_{2} \mathrm{Si}_{3} \mathrm{AlO}_{10}(\mathrm{OH})_{2}$ Muscovite \\
\hline q14-2 & $\mathrm{SiO}_{2}$ Kuarza low $\mathrm{KAl}_{2} \mathrm{Si}_{3} \mathrm{AlO}_{10}(\mathrm{OH})_{2}$ MuscoviteKAlSi $\mathrm{O}_{8}$ Microcline \\
\hline s6-1 & $\mathrm{SiO}_{2}$ Kuarza low $\mathrm{KAl}_{2} \mathrm{Si}_{3} \mathrm{AlO}_{10}(\mathrm{OH})_{2}$ Muscovite \\
\hline s6-2 & $\mathrm{SiO}_{2}$ Kuarza low $\mathrm{KAl}_{2} \mathrm{Si}_{3} \mathrm{AlO}_{10}(\mathrm{OH})_{2}$ Muscovite \\
\hline s6-3 & $\mathrm{SiO}_{2}$ Kuarza low $\mathrm{KAl}_{2} \mathrm{Si}_{3} \mathrm{AlO}_{10}(\mathrm{OH})_{2}$ Muscovite \\
\hline s12-1 & $\mathrm{SiO}_{2}$ Kuarza low $\mathrm{KAl}_{2} \mathrm{Si}_{3} \mathrm{AlO}_{10}(\mathrm{OH})_{2}$ Muscovite $\mathrm{KAlSi}_{3} \mathrm{O}_{8}$ Orthoclase \\
\hline s12-2 & $\mathrm{SiO}_{2}$ Kuarza low \\
\hline s12-3 & $\mathrm{SiO}_{2}$ Kuarza low $\mathrm{KAl}_{2} \mathrm{Si}_{3} \mathrm{AlO}_{10}(\mathrm{OH})_{2}$ Muscovite $\mathrm{FeAl}_{2} \mathrm{SiO}_{5}(\mathrm{OH})_{2}$ Chloritiod \\
\hline s20-1 & $\mathrm{SiO}_{2}$ Kuarza low $\mathrm{KAl}_{2} \mathrm{Si}_{3} \mathrm{AlO}_{10}(\mathrm{OH})_{2}$ Muscovite \\
\hline $\mathrm{s} 20-2$ & $\mathrm{SiO}_{2}$ Kuarza low $\mathrm{KAl}_{2} \mathrm{Si}_{3} \mathrm{AlO}_{10}(\mathrm{OH})_{2}$ Muscovite \\
\hline t16-1 & $\mathrm{SiO}_{2}$ Kuarza low $\mathrm{KAl}_{2} \mathrm{Si}_{3} \mathrm{AlO}_{10}(\mathrm{OH})_{2}$ Muscovite $\mathrm{KAlSi}_{3} \mathrm{O}_{8}$ Orthoclase $\mathrm{Al}_{2} \mathrm{Si}_{2} \mathrm{O}_{5}(\mathrm{OH})_{4}$ Kaolinite \\
\hline $\mathrm{t} 16-2$ & $\mathrm{SiO}_{2}$ Kuarza low $\mathrm{KAl}_{2} \mathrm{Si}_{3} \mathrm{AlO}_{10}(\mathrm{OH})_{2}$ Muscovite $\mathrm{KAl}_{2}\left(\mathrm{Si}_{3} \mathrm{AlO}_{10}\right)(\mathrm{OH})_{2}$ Illite \\
\hline t18-1 & $\mathrm{SiO}_{2}$ Kuarza low $\mathrm{KAl}_{2}\left(\mathrm{Si}_{3} \mathrm{AlO}_{10}\right)(\mathrm{OH})_{2}$ Illite $\mathrm{KAlSi}_{3} \mathrm{O}_{8}$ Orthoclase \\
\hline $\mathrm{t} 18-2$ & $\mathrm{SiO}_{2}$ Kuarza low $\mathrm{KAl}_{2} \mathrm{Si}_{3} \mathrm{AlO}_{10}(\mathrm{OH})_{2}$ Muscovite \\
\hline $\mathrm{t} 18-3$ & $\mathrm{SiO}_{2}$ Kuarza low $\mathrm{KAl}_{2} \mathrm{Si}_{3} \mathrm{AlO}_{10}(\mathrm{OH})_{2}$ Muscovite $\mathrm{KAlSi}_{3} \mathrm{O}_{8}$ Orthoclase \\
\hline u12-1 & $\mathrm{SiO}_{2}$ Kuarza low $\mathrm{KAl}_{2} \mathrm{Si}_{3} \mathrm{AlO}_{10}(\mathrm{OH})_{2}$ Muscovite \\
\hline u12-2 & $\begin{array}{l}\mathrm{SiO}_{2} \text { Kuarza low } \mathrm{KAl}_{2} \mathrm{Si}_{3} \mathrm{AlO}_{10}(\mathrm{OH})_{2} \text { Muscovite } \mathrm{Ca}_{2} \mathrm{Mg}_{5} \mathrm{Si}_{8} \mathrm{O}_{22}(\mathrm{OH}) \text { Tremolite } \\
\left(\mathrm{Al}(\mathrm{OH})_{2}\right)_{23} \mathrm{Al}\left(\mathrm{Si}_{2} \mathrm{Al}_{2} \mathrm{Al}_{23} \mathrm{O}_{10}\right)(\mathrm{OH})_{2} \text { Montmorillonite }\end{array}$ \\
\hline u14-1 & $\mathrm{SiO}_{2}$ Kuarza low $\mathrm{KAl}_{2} \mathrm{Si}_{3} \mathrm{AlO}_{10}(\mathrm{OH})_{2}$ Muscovite \\
\hline u15-1 & $\mathrm{SiO}_{2}$ Kuarza low $\mathrm{KAl}_{2} \mathrm{Si}_{3} \mathrm{AlO}_{10}(\mathrm{OH})_{2}$ Muscovite \\
\hline $\mathrm{u} 15-2$ & $\mathrm{SiO}_{2}$ Kuarza low $\mathrm{KAl}_{2} \mathrm{Si}_{3} \mathrm{AlO}_{10}(\mathrm{OH})_{2}$ Muscovite $\mathrm{KAlSi}_{3} \mathrm{O}_{8}$ Orthoclase \\
\hline
\end{tabular}

Bricks created and dried are then arranged and gathered in an area and then burnt using woodpile placed on top of the bricks. If the bricks arrangement is a lot, it is not impossible brick with the lowest and farthest position from the fire would experience low burning rate as compared to the ones outside or nearer to the fire. This is different when the bricks are burnt in the furnace where the high temperature in the furnace and the way bricks are arranged are more orderly would ensure the bricks to achieve a standard temperature.

Analysis of major elements done onto the brick samples at Candi Sungai Mas (Site 32/34) are shown in Table 2. Dry weight percentage of silica in between $66.72-81.06 \%$. Dry weight percentage for titanium is between 0.51 and $0.94 \%$. Iron contains dry weight percentage between 1.97 and $5.42 \%$. Dry weight percentage for aluminum is between 12.11 and $20.31 \%$. Mangan contains dry weight percentage between 0.01 and $0.06 \%$ whereas calcium contains dry weight percentage dry weight percentage between 0.08 and $0.37 \%$. Dry weight percentage for magnesium and sodium are between $0.01,1.07,0.50$ and $0.70 \%$. Potassium and phosphorus contain dry weight percentage between $0.33,2.94,0.31$ and $2.87 \%$.

Elements like silica, aluminum and ferum are elements containing a high dry weight percentage for brick samples at Candi Sungai Mas (Site 32/34). Scatter plot of $\mathrm{K}_{2} \mathrm{O}$ and $\mathrm{CaO}$ dry weight percentage (Raedt et al., 2000) is plotted to see the distribution of bricks substances whereby the purpose of this graph being plotted is because to differentiate every sample based on its main substance (Fig. 1). From observation towards the major elements content in the brick of Sungai Mas has shown that there are two sources has been used to make the brick at this site. The source containing high potassium substance is of samples like d14-2, i10, i7-2, q14-1, q14-2, s6-1, s6-2, s6-3, s12-1, t16-1, t16-2, t18-1, t18-3, u14-1, u15-1 and u15-2.

Another source found at this site and contained low potassium substance is of sample like d14-1, d14-3, i71, i7-3, s12-2, s12-3, s20-1, s20-2, t18-2, u12-1 and u12-2. This clearly show the brick maker at this site has used two or more different sources to make their construction bricks. The question now is whether these different source bricks is used to make the same construction structure or there is many construction structures in this area. This is because this site is a well known ancient port site in the 5-12th century.

The content of trace elements in the brick sample of Candi Sungai Mas (Site 32/34) is shown in Table 3. Trace elements such as $\mathrm{Ba}, \mathrm{Th}, \mathrm{Zr}, \mathrm{Rb}$ and $\mathrm{Zn}$ contain concentration more than $100 \mathrm{ppm}$ at most samples. The concentration range of $\mathrm{Ba}$ substance for every sample is between 217-362 ppm whereas Th substance is between 103-216 ppm. 
Am. J. Applied Sci., 9 (2): 196-201, 2012

Table 2: The content of major elements in ancient bricks from Candi Sungai Mas (Site 32/34)

\begin{tabular}{|c|c|c|c|c|c|c|c|c|c|c|}
\hline \multirow[b]{2}{*}{ Sample } & \multicolumn{10}{|c|}{ Dry Weight (\%) } \\
\hline & $\mathrm{Si}$ & $\mathrm{Ti}$ & $\mathrm{Fe}$ & $\mathrm{Al}$ & $\mathrm{Mn}$ & $\mathrm{Ca}$ & $\mathrm{Mg}$ & $\mathrm{Na}$ & $\mathrm{K}$ & $\mathrm{P}_{2} \mathrm{O}_{3}$ \\
\hline $\mathrm{d} 14-1$ & 80.26 & 0.80 & 2.52 & 13.23 & 0.04 & 0.15 & 0.01 & 0.58 & 0.33 & 0.55 \\
\hline d14-2 & 74.02 & 0.61 & 3.54 & 14.26 & 0.03 & 0.23 & 0.07 & 0.60 & 2.94 & 0.84 \\
\hline d14-3 & 81.06 & 0.78 & 2.44 & 13.76 & 0.02 & 0.08 & 0.01 & 0.50 & 0.43 & 0.41 \\
\hline i10 & 72.45 & 0.61 & 3.93 & 14.82 & 0.01 & 0.31 & 0.47 & 0.53 & 2.02 & 0.31 \\
\hline i7-1 & 74.26 & 0.78 & 2.02 & 12.96 & 0.01 & 0.15 & 0.01 & 0.51 & 0.64 & 1.92 \\
\hline i7-2 & 73.14 & 0.55 & 3.64 & 13.00 & 0.14 & 0.27 & 0.30 & 0.58 & 2.46 & 0.46 \\
\hline i7-3 & 69.75 & 0.94 & 5.42 & 20.17 & 0.01 & 0.09 & 0.63 & 0.60 & 0.92 & 0.23 \\
\hline q14-1 & 77.85 & 0.53 & 4.50 & 12.97 & 0.02 & 0.18 & 0.01 & 0.58 & 2.48 & 1.67 \\
\hline $\mathrm{q} 14-2$ & 77.36 & 0.50 & 3.13 & 12.12 & 0.02 & 0.20 & 0.26 & 0.61 & 2.76 & 0.73 \\
\hline s6-1 & 75.60 & 0.64 & 3.96 & 13.29 & 0.06 & 0.42 & 0.65 & 0.70 & 2.36 & 2.83 \\
\hline s6-2 & 78.26 & 0.52 & 3.29 & 12.18 & 0.03 & 0.27 & 0.52 & 0.58 & 2.36 & 0.29 \\
\hline s6-3 & 72.94 & 0.54 & 4.02 & 15.76 & 0.05 & 0.37 & 0.33 & 0.57 & 1.88 & 0.69 \\
\hline s12-1 & 76.62 & 0.64 & 3.25 & 13.01 & 0.03 & 0.33 & 0.49 & 0.58 & 2.48 & 0.42 \\
\hline s12-2 & 74.53 & 0.82 & 2.63 & 12.86 & 0.02 & 0.23 & 0.01 & 0.54 & 0.59 & 2.74 \\
\hline s12-3 & 66.72 & 0.96 & 3.18 & 17.58 & 0.01 & 0.23 & 0.01 & 0.70 & 0.67 & 2.87 \\
\hline s20-1 & 75.67 & 0.75 & 2.42 & 12.11 & 0.01 & 0.17 & 0.01 & 0.56 & 0.60 & 2.53 \\
\hline $\mathrm{s} 20-2$ & 73.96 & 0.79 & 1.97 & 13.19 & 0.01 & 0.21 & 0.01 & 0.57 & 0.40 & 2.22 \\
\hline t16-1 & 70.56 & 0.65 & 4.36 & 14.45 & 0.02 & 0.23 & 0.18 & 0.58 & 2.00 & 1.53 \\
\hline t16-2 & 73.59 & 0.61 & 4.73 & 14.91 & 0.04 & 0.22 & 1.07 & 0.63 & 2.36 & 0.16 \\
\hline $\mathrm{t} 18-1$ & 74.48 & 0.65 & 3.32 & 13.56 & 0.01 & 0.15 & 0.19 & 0.50 & 1.73 & 0.74 \\
\hline $\mathrm{t} 18-2$ & 72.52 & 0.79 & 2.53 & 14.19 & 0.02 & 0.10 & 0.01 & 0.58 & 0.47 & 1.66 \\
\hline t18-3 & 70.76 & 0.51 & 2.10 & 20.31 & 0.02 & 0.13 & 0.07 & 0.53 & 2.92 & 0.90 \\
\hline u12-1 & 68.12 & 0.79 & 3.47 & 15.99 & 0.02 & 0.26 & 0.01 & 0.56 & 0.69 & 2.63 \\
\hline u12-2 & 79.79 & 0.66 & 3.37 & 12.79 & 0.01 & 0.15 & 0.01 & 0.61 & 0.87 & 0.62 \\
\hline u14-1 & 79.50 & 0.57 & 3.28 & 12.65 & 0.02 & 0.23 & 0.53 & 0.51 & 2.01 & 0.29 \\
\hline u15-1 & 74.37 & 0.64 & 3.69 & 13.87 & 0.02 & 0.16 & 0.22 & 0.55 & 2.08 & 0.86 \\
\hline u15-2 & 74.12 & 0.61 & 4.06 & 14.39 & 0.03 & 0.25 & 0.51 & 0.58 & 2.48 & 0.27 \\
\hline
\end{tabular}

Table 3: The contents of trace elements in ancient bricks from Candi Sungai Mas (Site 32/34)

\begin{tabular}{|c|c|c|c|c|c|c|c|c|c|c|c|c|c|c|c|c|}
\hline \multirow[b]{2}{*}{ Sample } & \multicolumn{16}{|c|}{ Concentration $(\mu \mathrm{g} / \mathrm{g})$} \\
\hline & As & $\mathrm{Ba}$ & $\mathrm{La}$ & $\mathrm{Co}$ & $\mathrm{Cr}$ & $\mathrm{Cu}$ & $\mathrm{Ga}$ & $\mathrm{La}$ & $\mathrm{Nb}$ & $\mathrm{Ni}$ & $\mathrm{Pb}$ & $\mathrm{Rb}$ & $\mathrm{Hf}$ & $\mathrm{V}$ & $\mathrm{Zn}$ & $\mathrm{Zr}$ \\
\hline d14-1 & 18 & 324 & 62 & 14 & 94 & 34 & 22 & 62 & 40 & 20 & 65 & 36 & 13 & 95 & 127 & 558 \\
\hline d14-2 & 5 & 312 & 164 & 13 & 83 & 45 & 20 & 164 & 21 & 29 & 62 & 214 & 6 & 73 & 210 & 220 \\
\hline d14-3 & 18 & 243 & 155 & 10 & 91 & 24 & 23 & 155 & 32 & 20 & 8 & 45 & 14 & 103 & 93 & 559 \\
\hline i10 & 13 & 290 & 95 & 16 & 93 & 114 & 21 & 95 & 24 & 42 & 63 & 254 & 9 & 99 & 127 & 250 \\
\hline i7-1 & 22 & 284 & 74 & 9 & 99 & 62 & 23 & 74 & 31 & 18 & 62 & 92 & 12 & 181 & 227 & 453 \\
\hline i7-2 & 23 & 260 & 80 & 19 & 72 & 42 & 20 & 80 & 22 & 30 & 66 & 199 & 9 & 74 & 255 & 235 \\
\hline i7-3 & 5 & 252 & 149 & 28 & 105 & 34 & 24 & 149 & 35 & 24 & 68 & 114 & 7 & 110 & 109 & 310 \\
\hline q14-1 & 3 & 272 & 111 & 18 & 88 & 299 & 21 & 111 & 19 & 35 & 86 & 185 & 6 & 81 & 443 & 196 \\
\hline $\mathrm{q} 14-2$ & 6 & 249 & 83 & 20 & 70 & 85 & 17 & 83 & 18 & 15 & 44 & 229 & 8 & 65 & 108 & 198 \\
\hline s6-1 & 16 & 270 & 44 & 22 & 73 & 23 & 18 & 44 & 21 & 28 & 56 & 194 & 10 & 68 & 227 & 275 \\
\hline s6-2 & 20 & 274 & 114 & 25 & 73 & 70 & 19 & 114 & 19 & 26 & 52 & 204 & 10 & 67 & 186 & 235 \\
\hline s6-3 & 14 & 278 & 110 & 26 & 86 & 465 & 19 & 110 & 23 & 39 & 54 & 205 & 5 & 85 & 133 & 225 \\
\hline s12-1 & 5 & 273 & 77 & 3 & 78 & 70 & 22 & 77 & 28 & 24 & 60 & 204 & 9 & 73 & 106 & 332 \\
\hline s12-2 & 29 & 404 & 103 & 8 & 77 & 163 & 23 & 103 & 30 & 22 & 37 & 26 & 12 & 96 & 132 & 512 \\
\hline s12-3 & 23 & 334 & 66 & 17 & 92 & 209 & 26 & 66 & 34 & 28 & 34 & 109 & 9 & 119 & 206 & 458 \\
\hline s20-1 & 32 & 257 & 83 & 8 & 81 & 111 & 20 & 83 & 28 & 16 & 38 & 88 & 11 & 100 & 68 & 424 \\
\hline s $20-2$ & 46 & 262 & 46 & 17 & 85 & 185 & 26 & 46 & 30 & 20 & 16 & 68 & 12 & 90 & 110 & 515 \\
\hline $\mathrm{t} 16-1$ & 6 & 306 & 120 & 26 & 99 & 247 & 23 & 120 & 22 & 37 & 63 & 192 & 8 & 95 & 179 & 232 \\
\hline $\mathrm{t} 16-2$ & 4 & 251 & 83 & 30 & 82 & 33 & 20 & 83 & 26 & 26 & 23 & 188 & 10 & 72 & 100 & 217 \\
\hline $\mathrm{t} 18-1$ & 19 & 278 & 94 & 3 & 81 & 153 & 22 & 94 & 24 & 34 & 53 & 184 & 9 & 89 & 144 & 324 \\
\hline $\mathrm{t} 18-2$ & 52 & 265 & 84 & 17 & 84 & 129 & 21 & 84 & 27 & 29 & 27 & 123 & 11 & 116 & 177 & 363 \\
\hline $\mathrm{t} 18-3$ & 11 & 220 & 117 & 11 & 58 & 57 & 31 & 117 & 33 & 24 & 113 & 337 & 9 & 56 & 114 & 283 \\
\hline u12-1 & 32 & 362 & 104 & 20 & 101 & 162 & 23 & 104 & 29 & 39 & 107 & 114 & 11 & 125 & 178 & 368 \\
\hline u12-2 & 5 & 294 & 115 & 21 & 91 & 63 & 20 & 115 & 28 & 17 & 18 & 101 & 5 & 90 & 38 & 334 \\
\hline U14-1 & 9 & 217 & 135 & 18 & 80 & 41 & 22 & 135 & 25 & 25 & 38 & 183 & 6 & 66 & 80 & 294 \\
\hline U15-1 & 6 & 284 & 85 & 17 & 88 & 144 & 17 & 85 & 23 & 31 & 57 & 184 & 10 & 79 & 203 & 323 \\
\hline U15-2 & 9 & 247 & 110 & 12 & 83 & 38 & 20 & 110 & 22 & 30 & 45 & 193 & 10 & 81 & 90 & 235 \\
\hline
\end{tabular}




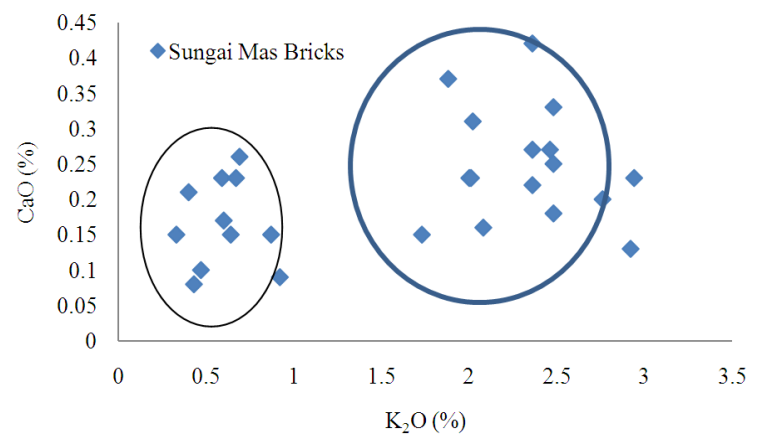

Fig. 1: Scatter plot of $\mathrm{K}_{2} \mathrm{O}$ and $\mathrm{CaO}$ dry weight percentage in Candi Sungai Mas (Site 32/34) brick samples

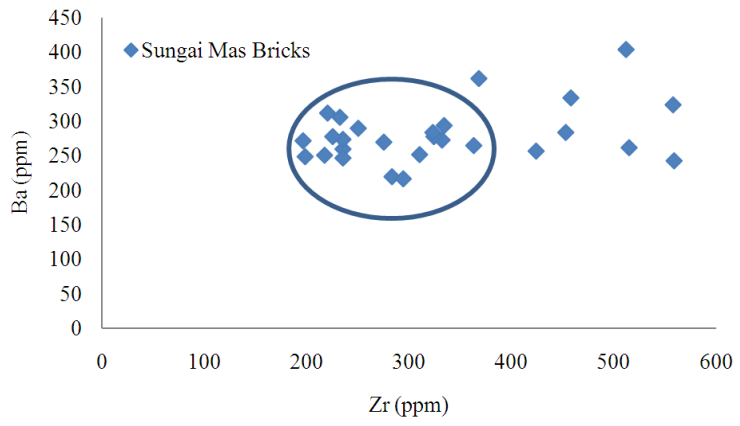

Fig. 2: Scatter plot of $\mathrm{Zr}$ and Ba concentration of Candi Sungai Mas (Site 32/34) brick samples

The concentration range of every sample for $\mathrm{Zr}$ substance is between 198-559 ppm whereas for $\mathrm{Rb}$ substance is between 36-337ppm. Zn content in the brick sample of Sungai Mas is between 38-443ppm.

Scatter plot of $\mathrm{Zr}$ and $\mathrm{Ba}$ concentration has been plotted (Raedt et al., 2000) to see the trace substances distribution for bricks at Sungai Mas (Fig. 2) and the result show that there is the same trace substances distribution. The observation towards the trace substances content also shows there is two or more clay sources used to make brick at this Kampung Sungai Mas. Looking at the brick main substance distribution at Sungai Mas, the result also shows that there is two or more clay sources used to make the ancient structures at the Historic Land Site of Kampung Sungai Mas.

\section{CONCLUSION}

The brick burning technology used in this site is open burning. This has caused some brick to get insufficient temperature and fragile. This can be seen at the excavation of $\mathrm{X}$ phase where there is brick which is brittle and fragile. The burning temperature is between $550-800^{\circ} \mathrm{C}$. The presence of minerals such as kaolinite, illite and montmorillonite in t16-1, t16-2 and u12-2 samples show that there are bricks which experience burning at the temperature below $550^{\circ} \mathrm{C}$ and bricks which are brittle and breakable. Based on the content analysis of minerals and compression strength test is obvious that the burning at a low temperature will caused a low compression strength of the brick.

After analyzing the data gathered from the analysis it is found that there is two main groups used as clay sources in at the study area. The first group is made up of d14-1, d14-3, i7-1, i7-3, s12-2, s12-3, s20-1, s20-2, t18-2, u12-1 and u12-2 samples. These samples contain main substance content and trace substance which is nearly the same and it is suggested that these samples is using the same source. The mineral content in these samples are nearly the same whereby the observed mineral obtained are such as quartz and muscovite. Only s12-3 and s12-3 samples contain different mineral such as chloritiod mineral for s12-3 and tremolite and montmorillonite for u12-2 sample. After the data from these samples are matched with clay data studied before this around the research site, it is found that these brick samples do not show any similarity in terms of chemistry composition content with clay chemistry composition around Historic Land Site of Kampung Sungai Mas, Kota Kuala Muda, Kedah. This shows that this brick sample does not use clay source found around Kampung Sungai Mas.

The pottery makers normally take the clay source at the distance of 7-10 km from their industry area and since the area around Kampung Sungai Mas has a lot of clay source, pottery makers in this area may not has used sources from outside or far from their areas. These bricks might be possibly brought from outside of Kampung Sungai Mas to build up specific structures such as temple, port structure since the site standard which function as an ancient port.

Different from brick samples like d14-2, i10, i7-2, q14-1, q14-2, s6-1, s6-2, s6-3, s12-1, t16-1, t16-2, t18$1, \mathrm{t} 18-3, \mathrm{u} 14-1, \mathrm{u} 15-1$ and $\mathrm{u} 15-2$ which has the same chemistry composition content with the clay chemistry composition around Historic Land Site of Kampung Sungai Mas area. These bricks are similar to the clay taken from around Kota District area, Sungai Terus and Sungai Muda. This shows that this area once has skillful brick makers whereby the bricks used are produced on their own without bringing in brick from outside. Findings from the study indicates that there are more than one clay source used to make the bricks of Candi Sungai Mas (Site 32/34). One of the sources has been taken from Muda River valley and the other sources came from Bujang River valley. 


\section{REFERENCES}

Abdullah, M.Z., A. Saat and Z. Hamzah, 2011. Optimization of energy dispersive $\mathrm{x}$-ray fluorescence spectrometer to analyze heavy metals in moss samples. Am. J. Eng. Applied Sci., 4: 355362. DOI: 10.3844/ajeassp.2011.355.362

Raedt, I.D., B. Vekemans, K. Jensen and F. Adam, 2000. Synchrotron light through ancient glass. Europhysics News, 31: 15-15. DOI: 10.1051/epn:2000604

Hamzah, Z., S.D. Riduan and A. Saat, 2011. Determination of sediment profile for ${ }^{210} \mathrm{~Pb}, \mathrm{~Pb}, \mathrm{U}$ and Th from Sultan Abu Bakar Dam due to soil erosion from highland agriculture area, Cameron Highlands, Malaysia. Am. J. Environ. Sci., 7: 263268. DOI: 10.3844/ajessp.2011.263.268

Rahman, H.S.B.N.A. and O.B.M. Yatim, 1990. Antiquities of Bujang Valley. 1st Edn., Museum Association of Malaysia, Kuala Lumpur, ISBN: 9679935043, pp: 115.

Rahman, N.H.S.B.N.A. and K.B. Zakaria, 1993. Recent archaeological discoveries in Sungai Mas, Kuala Muda, Kedah. J. Malaysian Branch Royal Asiatic Soc., 66: 73-80.

Ramli, Z., K. Zakaria and M. Nordin, 2007. Kajian komposisi kimia kalam semah dan tembikar tanah yang ditemui di Gua Bukit Chawas. J. Arkeologi Malaysia, 20: 22-63.

Ramli, Z., N.H. Shuhaimi and N.A. Rahman, 2009. Beads trade in Peninsula Malaysia: Based on archaeological evidences. Eur. J. Soc. Sci., 10: 585-593.
Ridha, N.J., W.M.M. Yunus, S.A. Halim and Z.A. Talib, 2009. Effect of Sr substitution on structure and thermal diffusivity of $\mathrm{Ba} 1-\mathrm{xSrxTiO} 3$ ceramic. Am. J. Eng. Applied Sci., 2: 661-664. DOI: 10.3844/ajeassp.2009.661.664

Ramli, Z., N.H.S.N. Abdul Rahman and A.L. Samian, 2011a. X-ray fluorescent analysis on Indo-Pacific glass beads from Sungai Mas archaeological sites, Kedah, Malaysia. J. Radioanalytical Nuclear Chem., 287: 741-747. DOI: 10.1007/s10967-0100920-y

Ramli, Z., N.H.S.N. Abdul Rahman, A. Jusoh and Y. Sauman, 2011b. X-ray diffraction and X-ray fluorescent analyses of prehistoric pottery shards from Ulu Kelantan. Am. J. Applied Sci., 8: 13371342. DOI: $10.3844 / a j a s s p .2011 .1337 .1342$

Shuhaimi, N.H., 1984. Art, archaeology and the early kingdoms in the Malay Peninsula and Sumatra, c.400-1400 A.D. University of London, London, pp: 651.

Chia, S.M.S., 1998. Indigenous prehistoric pottery and technology in Peninsular Malaysia. Malaysia Museums J.

Woon, H.S., K.P. Lim, N. Puteri, R. Rozaimah and C.Y. Tan, 2009. Synthesis and characterization of hot-roll and cold-roll byproduct-derived strontium hard ferrites. Am. J. Eng. Applied Sci., 2: 580-583. DOI: 10.3844/ajeassp.2009.580.583 